\title{
Effects of simulated acid rain on tropical trees of the coastal zone of Campeche, Mexico
}

\author{
R. M. Cerón, J. G. Cerón, J. J. Guerra, E. López, E. Endañu, \\ M. Ramírez, M. García, R. Sánchez \& S. Mendoza \\ Universidad Autónoma del Carmen, México
}

\begin{abstract}
Native trees species of the coastal zone of Campeche Mexico belonging to different families (Blood wood tree (Haematoxylum campechianum L.), White mangrove (Laguncularia racemosa (L.) Gaertn), Red mangrove (Rhizophora mangle L.), Button mangrove (Conocarpus erectus L.), Pink flower tree (Tabebuia rosea Bertol), Mahogany (Switenia macrophyla King) and Red cedar (Cedrela odorata L.)) were exposed to simulated acid rain for six weeks to assess visible foliar damage and effects on sulphur, nutrients, and photosynthetic pigment contents. A total of 245 seedlings were exposed four times a week from June to July under controlled conditions by using a simulated rainwater distribution system designed to reproduce rain events of $10 \mathrm{~mm}$. Six treatments with five repetitions each were established at drought and irrigation conditions at different $\mathrm{pH}$ values. The results suggest that the water stress condition is related to the severity of the effects shown by individuals exposed to acid rain at $\mathrm{pH}$ values of 2.0 and 3.0. A significant increase in sulphur contents was observed on mature leaf tissues, being greater in the Mahogany, Red Cedar and Blood wood trees at $\mathrm{pH} 2$ treatment under drought conditions. The chlorophyll $\mathrm{a} / \mathrm{b}$ ratio showed a significant decrease in the Mahogany, White Mangrove and Blood wood trees, and nutrient levels were sensitive to the lowest $\mathrm{pH}$ values. According to the results, it could be observed that the Red mangrove, Button mangrove, Red cedar and Blood wood trees were more sensitive to acid rain. The Horsfall-Barratt method was applied to develop a severity scale; however, it is necessary to conduct a field survey for long-term exposure in parcels focused on sensible species to obtain a more precise scale.
\end{abstract}

Keywords: tropical trees, simulated acid rain, nutrients, visible damage, photosynthetic pigments. 


\section{Introduction}

Tree growth results from multiple interacting physiological processes influenced by an inherited genetic constitution and the environment. Air pollutants that limit the carbon gain or nutrient availability may, however, suppress the growth rate and total biomass production, and thus affect the allocation pattern (McLaughlin and Shriner [1]; Troiano et al. [2]).

An increase in precipitation acidity predisposes tree seedlings to a number of environmental stresses, which are reflected in seedling germination, growth and survival (Percy [3]; Jacobson et al. [4]; Shepard et al. [5]). However, considerable differences have been reported in the response of individual species to acid rain (Percy [3]; Abouguendia and Baschak [6]; Billen et al. [7]). Such variability may result from genetic differences in susceptibility, nutrient imbalances in the soil or foliage, or from the direct influence of acid precipitation on the foliage. There has been considerable speculation about forest decline related to acid deposition due to the main physiological mechanisms for observed responses remain unclear (Bäck et al. [8]). The reasons for this uncertainty include some factors as the variability in tree growth due to site, competition, tree age and genotype, and the fact that nitrogen compounds of the acid rain can act as fertilizer to improve tree growth.

Experiments of simulated acid rain have been usually considered and designed by many researchers as an effective way for determining the relative importance of the effects attributed to acid rain, and great progress has been made so far (Houbao and Chuanrong [9]). Effects of simulated acid rain (SAR) have been quantified by measurements of tissue damage, physiological response and even by observed changes in host-parasite relationships (Evans et al. [10]; Ferenbaugh [11]; Jacobson and Van Leuken [12]; Shriner [13]; Wood and Bormann [14]). Extremely low pH level such as pH 2.0 seems to induce severe necrosis in plants (Haines and Carlson [15]; Shriner et al. [16]; Kohno et al. [17]). According to Kohno et al. [17] some of broad leaf trees exposed to SAR with a pH 3.0 showed acute visible injuries. At this time, it appears that rain with $\mathrm{pH}$ values above 4.0 applied in a routine manner to the vegetation, does not cause detrimental effects, however, the frequency of occurrence of rain events below pH 4.0 is important.

Tamm and Popovic [18] and Tveite et al. [19] reported long-term exposure experiments of SAR in the field grown Pinus sylvestris. However, such field experiments have a lot of limitations to be carried out. In contrast, many shortterm exposure experiments of SAR (Izuta and Miwa [20]; Miwa et al. [21]; Matsumoto and Maruyama [22]; Shriner et al. [16]) are available in the literature. Several works have demonstrated that sensitive plants response quickly to acid rain episodes within few of days after the exposure, showing typical symptoms characteristics, so this property can be used by scientists to define some species as biological indicators. Biological indicators are a common tool for toxicologists. Because of instrument networks used to monitoring of air quality need constant calibration procedures and repairs, less expensive but reliable methods are required, and the use of plants for studying air quality is 
quite appropriate. For this reason, it is necessary to know which plants react in what ways to one or several pollutants, and which conditions govern the susceptibility of a particular plant to a specific pollutant or a mix of them. The purpose of this paper was to assess the visible damage and the effects on sulphur, nutrients and photosynthetic pigments levels as a consequence of acid rain on endemic and protected vegetation species of Campeche, Mexico, as well as identify the most sensitive species to acid rain to be proposed as regional bioindicators of atmospheric pollution.

\section{Methodology}

A total of 7 species of tropical trees were selected for this research, considering their regional importance in the coastal zone of Campeche State (species protected and endemic were included). Red mangrove, Button mangrove, White mangrove, Mahogany, Pink Flower Tree, and Blood Wood Tree are protected species. Red Cedar, White Mangrove and Blood Wood Tree are endemic species of the studied region, Red Cedar being a threatened specie according to NOM059-SEMARNAT-2001 [23].

During propagation stage of species, periodically, sanitation inspections of seedlings were carried out to assure the good health of the individuals. For each of the species, 35 seedlings were potted into $2 \mathrm{~kg}$ pots in a mixture of soil and compost and placed in a greenhouse to assure uniform conditions in their growth. Each Potted seedling was labelled with the name of the specie and the number of individual. Individuals labelled from 1 to 10 , were assigned to treatments under drought conditions, and the remaining individuals were assigned to treatments under irrigation conditions. A general diagnostic about the health conditions was carried out by measuring physiological characteristics as height, stem diameter, width treetop, weight, leaf size, number and colour of leaves, and the presence of previous diseases, injuries from insects or mechanical damage.

Irrigation of seedlings was done with well water whose quality was verified by continuous monitoring. Seedlings were irrigated daily using an automatic system in a greenhouse specially designed to avoid the natural rainwater.

Trees were treated four times a week during six weeks from June to July 2008 with SAR at $\mathrm{pH}$ values of 2.0, 3.0, 4.0 and 5.6, produced by adding $\mathrm{H}_{2} \mathrm{SO}_{4}$ to a base solution. $\mathrm{pH}$ values and the total amount of daily rainfall $(10 \mathrm{~mm})$ were selected with base on regional data recorded the last ten years. Two sets of experiments were done; one of them was carried out under drought conditions: the SAR exposure regime was the same as irrigation conditions but individuals were not irrigated during all the study to simulate the predisposing water stress condition. On the other hand, the second set of experiments was carried out under irrigation conditions to simulate acid rain events during rainy season; in this case, individuals were subjected only to automatic irrigation system avoiding natural rainwater.

Six treatments with five replications for each specie were established: 1) SAR at $\mathrm{pH} 2.0$ under drought conditions (individuals labelled from 1 to 5), 2) SAR at $\mathrm{pH} 3.0$ under drought conditions (individuals labelled from 6 to 10), 3) SAR at 
$\mathrm{pH} 5.6$ under irrigation conditions (individuals labelled from 11 to 15 ), 4) SAR at $\mathrm{pH} 4.0$ under irrigation conditions (individuals labelled from 16 to 20), 5) $\mathrm{SAR}$ at $\mathrm{pH} 3.0$ under irrigation conditions (individuals labelled from 21 to 25), 6) SAR at $\mathrm{pH} 2.0$ under irrigation conditions (individuals labelled as 26 to 30). Individuals labelled from 31 to 35 were used as control individuals so they were not exposed to SAR.

Tissue samples of young and mature leaves were collected at the beginning, in the middle and at the end of the exposures. Each sample was numbered, identified, digitalized to be processed by Photoshop and Image Tools software, and temporally stored under refrigeration in airtight plastic bags until subsequent analysis. Vegetal tissue samples were weighed in fresh, and were divided in two halves, one of them was grinded and used for chlorophyll determination on acetone extracts reading the absorbances at 665, 663.2, 646.8, 470 and $430 \mathrm{~nm}$. Chlorophyll alpha, chlorophyll beta, charotenoids and total chlorophyll content (mg fresh weigh $\mathrm{l}^{-1}$ ) were estimated from Lichtenthaler equations.

The second half was subdivided into two halves, each one of them was dried at $80{ }^{\circ} \mathrm{C}$ during 24 hours and weighed for sulphur and nutrients determination. The first half dried was grinded and digested with nitric and hydrochloric acids in Teflon ${ }^{\circledR}$ closed flasks (Cole-Parmer) of $100 \mathrm{ml}$, using autoclave equipment as an energy source. Subsequently, digested samples were filtered to determine sulphur as sulphate by turbidimetric method reading the absorbance of barium sulphate at $420 \mathrm{~nm}$. The second half dried was grinded and digested with nitric, sulphuric and hydrochloric acids in Teflon ${ }^{\circledR}$ closed flasks (Cole-Parmer) of 100 $\mathrm{ml}$, using autoclave equipment as an energy source. Subsequently, digested samples were filtered to determine $\mathrm{Ca}, \mathrm{K}, \mathrm{Mg}$ and $\mathrm{Mn}$ by atomic absorption spectrophotometry.

Data statistical analysis was carried out by using SAS [24], for each treatment (total chlorophyll, chlorophyll alpha, chlorophyll beta, charotenoids, chlorophyll alpha/beta ratio, nutrients and sulphur) for each collect at $\mathrm{p} \leq 0.05$. Variance analysis was carried out by using Duncan Method and a correlation was applied to data using Pearson method. To process digitalized images Adobe Photoshop Cs was applied, and healthy and injured areas were calculated by using Image Tool for Windows V. 1.28 (Osada and Mora [25]). Subsequently, Horsfall-Barrat method and 2 LOG $V 1.0$ software were used to generate severity scales and charts to know the damage in field.

\section{Results and discussion}

\subsection{Acute visible symptoms and severity scale}

In the case of the three species of mangrove (red, white and button), exposure of $\mathrm{SAR}$ at $\mathrm{pH} 2$ and 3 induced reddish-brown necrotic blots and chlorosis symptoms between veins and in some cases, injuries appear as brown blots in the tips of the leaves. Individuals of Mahogany, red cedar, blood wood tree and pink flower tree showed visible foliar damage (necrosis and chlorosis symptoms) when they were exposed to SAR at $\mathrm{pH} 2$ and 3 both dry conditions as irrigation 
conditions. A diffuse green coloration was observed in some individuals, the affected areas showed a typical bleached of decomposition of pigments (chlorosis) reported for damage induced by atmospheric pollutants. These visible injuries were more evident on mature leaves with treatments under drought conditions.

A severity scale was developed by using digitalized images, and injured areas were obtained applying Image Tool for windows v. 1.28. In spite of, severity charts and scales were obtained by applying Horsfall-Barrat method and 2 LOG v. 1.0 software, it is necessary to conduct field survey for long-term exposures in parcels focused on sensible species to obtain a more accurate scale.

\subsection{SAR effects on photosynthetic pigments levels}

Decomposition of photosynthetic pigments has been related to the effects of atmospheric pollutants on vegetation. It has been demonstrated that pollutants as $\mathrm{SO}_{2}, \mathrm{O}_{3}$ and acid rain induce the formation of free radicals in the cell. Therefore, when accumulation of radicals exceeds the capacity of detoxification of the plant, photo-oxidative injuries can be generated in the pigment-protein system.

Besides the content of pigments, their relative ratios also can be affected. A decrease in the chlorophyll $\mathrm{a} / \mathrm{b}$ ratio is a good indicator of damage by photooxidation process in leaves. From protective function given by charotenoids on

Table 1: Decreasing percentages of photosynthetic pigments for species of mangrove.

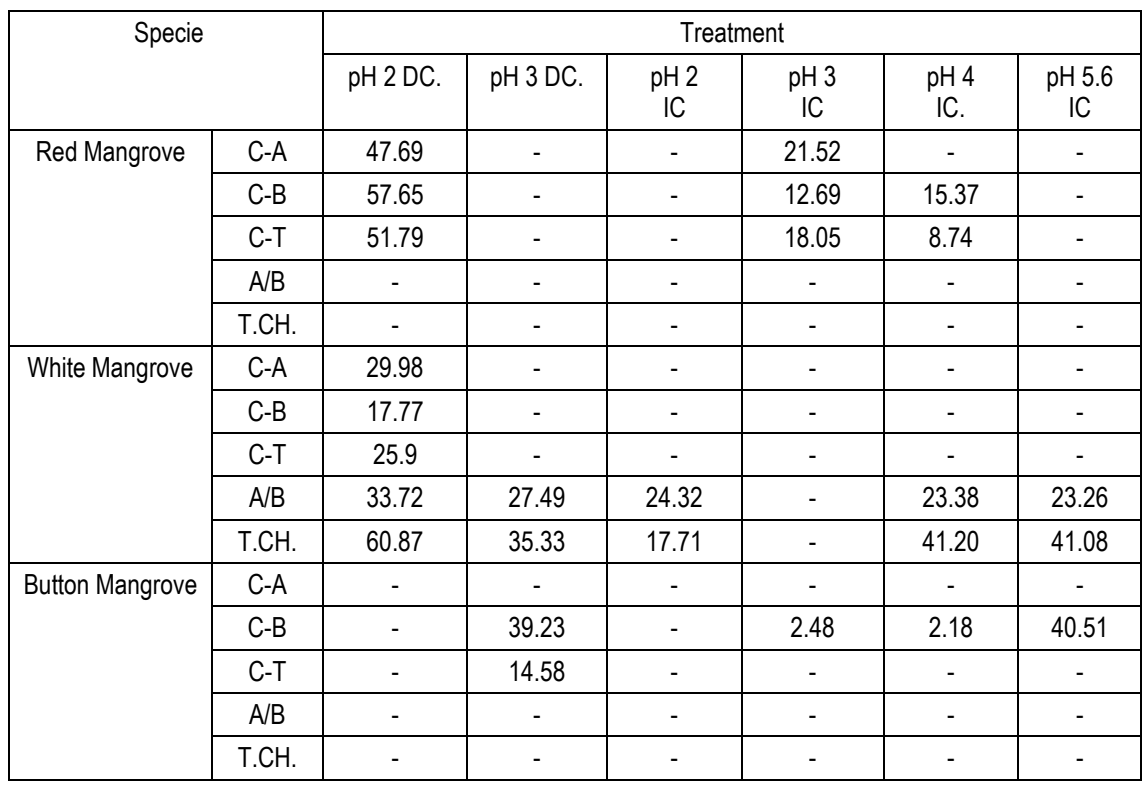

DC: Dry conditions; IC: Irrigation conditions; C-A: Chlorophyll-A; C-B: Chlorophyll-B;

C-T: Total Chlorophyll, A/B: Chlorophyll A/B ratio; T.CH: Total Charotenoids.

- Significant differences were not found. 
chlorophyll, a decrease in the content of them can be used as an indicator of direct photo-oxidation of pigments.

Photosynthetic pigments were quantified before and after the controlled exposure to SAR. In Table 1, decreasing percentages in photosynthetic pigments induced by SAR treatments for three species of mangrove are showed. It can be observed that chlorophyll-a, chlorophyll-b, and total chlorophyll were influenced by SAR treatments in the case of red and white mangrove at $\mathrm{pH} 2$ under dry conditions, being this decrease more evident in red mangrove. On the other hand, the chlorophyll $\mathrm{a} / \mathrm{b}$ ratio and the total content of charotenoids decreased in all treatments applied to white mangrove.

From results reported in Table 2, it can be observed that chlorophyll-a, chlorophyll-b, and total chlorophyll were influenced by SAR treatments in the case of Red Cedar and Pink Flower Tree at pH 2 and 3 such as under dry conditions as irrigation conditions, being this decrease more evident in pink

Table 2: Decreasing percentages of photosynthetic pigments for forestry species.

\begin{tabular}{|c|c|c|c|c|c|c|c|}
\hline \multicolumn{2}{|l|}{ Specie } & \multicolumn{6}{|c|}{ Treatment } \\
\hline Mahogany & C-A & $\begin{array}{c}\mathrm{pH} 2 \mathrm{DC} \\
-\end{array}$ & $\begin{array}{c}\mathrm{pH} 3 \mathrm{DC} \\
-\end{array}$ & $\begin{array}{c}\begin{array}{c}\mathrm{pH} 2 \\
\mathrm{IC}\end{array} \\
7.86 \\
\end{array}$ & $\begin{array}{c}\mathrm{pH} \mathrm{3} \\
\mathrm{IC} \\
-\end{array}$ & $\begin{array}{c}\mathrm{pH} 4 \\
\mathrm{IC} \\
-\end{array}$ & $\begin{array}{c}\mathrm{pH} 5.6 \mathrm{IC} \\
-\end{array}$ \\
\hline & C-B & - & - & - & - & - & - \\
\hline & C-T & - & - & 2.91 & - & - & - \\
\hline & $A / B$ & 7.23 & 21.26 & 10.91 & - & 35.55 & 20.01 \\
\hline & T.CH. & - & - & 18.64 & - & - & - \\
\hline \multirow[t]{5}{*}{ Red Cedar } & C-A & - & - & 29.25 & 22.76 & 42.28 & - \\
\hline & C-B & - & 36.54 & 37.78 & 55.42 & 56.84 & 13.75 \\
\hline & C-T & - & 14.72 & 32.59 & 36.62 & 51.40 & - \\
\hline & $A / B$ & - & - & - & - & - & - \\
\hline & T.CH. & - & - & 64.62 & 36.42 & - & 23.74 \\
\hline \multirow[t]{5}{*}{ Blood Wood Tree } & C-A & 19.43 & - & - & - & - & - \\
\hline & C-B & 56.36 & - & - & 58.26 & - & - \\
\hline & C-T & 41.39 & - & - & 36.29 & - & - \\
\hline & $A / B$ & 31.44 & - & - & - & - & - \\
\hline & T.CH. & 12.10 & 5.91 & 1.31 & - & - & - \\
\hline \multirow[t]{5}{*}{ Pink Flower Tree } & C-A & 66.55 & 45.09 & 52.98 & 41.47 & - & - \\
\hline & C-B & 75.51 & 52.62 & 30.74 & 43.91 & 20.84 & 10.81 \\
\hline & C-T & 66.87 & 48.47 & 42.72 & 42.49 & - & - \\
\hline & $A / B$ & - & - & 52.54 & - & - & - \\
\hline & T.CH. & 48.72 & 30.95 & 77.11 & 24.06 & - & - \\
\hline
\end{tabular}

DC: Dry Conditions; IC: Irrigation Conditions; C-A: Chlorophyll-A; C-B: Chlorophyll-B;

C-T: Total Chlorophyll, A/B: Chlorophyll A/B ratio; T.CH: Total Charotenoids.

-Significant differences were not found. 
flower tree under dry conditions. On the other hand, Mahogany and Blood Wood Tree individuals showed more resistance to effects on photosynthetic pigments induced by SAR. Results suggest that SAR does not predispose Mahogany to drought injuries related to decreasing of photosynthetic pigments. However, in spite of chlorophyll levels in Mahogany individuals were not affected directly by SAR, the chlorophyll $\mathrm{a} / \mathrm{b}$ ratio decreased in the most of treatments applied. Finally, it can be observed that the total content of charotenoids was affected by SAR treatments in the case of Red Cedar, Blood Wood Tree and Pink Flower Tree.

\subsection{SAR effects on sulphur levels}

In some regions of Europe Central, characterized by soils with a low buffer capacity, foliar concentration of sulphur is a good indicator of atmospheric pollution and is related to accumulation of sulphates as a result of acid deposition. Sulphur is an essential component of proteins and other organic compounds that play an important role in the nutrition process of the plants, however, sulphur in excess from acid rain cannot be eliminated by detoxification processes and it is accumulated as sulphate in cell vacuole of mesophyll, with a subsequent cation-anion imbalance. Bäck et al. [8] reported that sulphur accumulation in the needles and roots of irrigated pine and spruce with SAR treatments was greater compared with the control treatment. Sulphur levels were quantified before and after the controlled exposure to SAR. In Table 3, increasing percentages in sulphur levels induced by SAR treatments for three species of mangrove can be observed.

From results reported in Table 3, it can be observed that sulphur levels were influenced by SAR treatments for the three species of mangrove at $\mathrm{pH} 2$ and 3 under dry conditions, being this decrease more evident in red and white mangrove. On the other hand, forestry species showed an evident influence on sulphur levels induced by SAR treatments. In all treatments applied, forestry species showed increasing percentages greater than $75 \%$, being this increase more evident at dry conditions, in special for mature leaves tissues of Mahogany and Blood Wood Tree, suggesting a senescence acceleration effect induced by SAR.

Table 3: Increasing percentages of sulphur levels for mangrove species.

\begin{tabular}{|l|c|c|c|c|c|c|}
\hline \multirow{2}{*}{ Specie } & \multicolumn{6}{c|}{ Treatment } \\
\cline { 2 - 7 } & $\mathrm{pH} 2 \mathrm{DC}$ & $\mathrm{pH} 3 \mathrm{DC}$ & $\begin{array}{c}\mathrm{pH} 2 \\
\mathrm{IC}\end{array}$ & $\begin{array}{c}\mathrm{pH} 3 \\
\mathrm{IC}\end{array}$ & $\begin{array}{c}\mathrm{pH} 4 \\
\mathrm{IC}\end{array}$ & $\mathrm{pH} 5.6 \mathrm{IC}$ \\
\hline Red Mangrove & 79.33 & 198.97 & - & - & - & - \\
\hline White Mangrove & 87.41 & 323.43 & - & - & 297.26 & 1691.11 \\
\hline Button Mangrove & 73.72 & 28.35 & - & 30.56 & 0.32 & - \\
\hline
\end{tabular}

DC: Dry Conditions; IC: Irrigation Conditions

- Significant differences were not found. 


\subsection{SAR effects on elemental concentration in tissues}

Deposition of acids from the atmosphere onto forest floors may gradually increase soil acidity. Soil acidification leads to an increase in the rates of leaching of base cations such as $\mathrm{Ca}, \mathrm{Mg}$ and $\mathrm{K}$ from the rhizosphere soil, which may cause nutrients imbalance in forest tree species (Izuta et al. [26]). However, Hogan [27] did not find a clear indication that foliar levels of calcium, potassium, magnesium, manganese, phosphorous, iron and aluminium had been substantially altered over the short term by SAR applied to sugar maple. On the other hand, some authors (Bäck et al. [8]; Izuta et al. [28]; Shan et al. [29]) reported that $\mathrm{Mn}$ concentrations in needles and roots of seedlings increased in $\mathrm{SAR}$ treatments in comparison with control treatment; whereas $\mathrm{K}$ and $\mathrm{Mg}$

Table 4: $\quad$ Potassium levels (\%) in plant tissues before and after SAR.

\begin{tabular}{|l|c|c|c|c|c|c|c|c|c|c|c|c|}
\hline \multirow{3}{*}{ Specie } & \multicolumn{10}{|c|}{ Treatments } \\
\cline { 2 - 16 } & $\begin{array}{c}|c| \\
\mathrm{pH} 2 \\
\mathrm{DC}\end{array}$ & \multicolumn{2}{c|}{$\begin{array}{c}\mathrm{pH} 3 \\
\mathrm{DC}\end{array}$} & \multicolumn{2}{c|}{$\begin{array}{c}\mathrm{pH} 2 \\
\mathrm{IC}\end{array}$} & \multicolumn{2}{c|}{$\begin{array}{c}\mathrm{pH} \mathrm{3} \\
\text { IC }\end{array}$} & \multicolumn{2}{c|}{$\begin{array}{c}\mathrm{pH} 4 \\
\text { IC }\end{array}$} & \multicolumn{2}{c|}{$\begin{array}{c}\mathrm{pH} 5.6 \\
\text { IC }\end{array}$} \\
\cline { 2 - 16 } & $\mathrm{B}$ & $\mathrm{A}$ & $\mathrm{B}$ & $\mathrm{A}$ & $\mathrm{B}$ & $\mathrm{A}$ & $\mathrm{B}$ & $\mathrm{A}$ & $\mathrm{B}$ & $\mathrm{A}$ & $\mathrm{B}$ & $\mathrm{A}$ \\
\hline Red Mangrove & 4.89 & 1.97 & 6.02 & 4.54 & 6.19 & 3.95 & 3.5 & 3.8 & 3.14 & 4.09 & 3.8 & 4.1 \\
\hline White Mangrove & 6.52 & 2.52 & 7.89 & 2.35 & 8.98 & 2.42 & 10.1 & 0.51 & 6.47 & 2.98 & 4.76 & 1.09 \\
\hline Button Mangrove & 1.85 & 0.67 & 1.53 & 0.99 & 2.46 & 0.99 & 0.96 & 0.64 & 0.92 & 1.12 & 1.75 & 0.64 \\
\hline Mahogany & 4.62 & 2.35 & 5.14 & 1.66 & 4.58 & 1.24 & 3.98 & 2.37 & 3.77 & 2.42 & 2.04 & 1.09 \\
\hline Red Cedar & 15.4 & 4.21 & 11.3 & 4.4 & 12.2 & 2.48 & 11.5 & 2.42 & 15.2 & 1.36 & 13.2 & 3.66 \\
\hline Blood wood tree & 12.8 & 1.83 & 13.7 & 1.89 & 12.4 & 1.12 & 12.2 & 4.83 & 16.08 & 1.17 & 11.9 & 2.28 \\
\hline Pink flower tree & 5.21 & 1.64 & 6.16 & 1.85 & 7.3 & 1.28 & 6.0 & 1.88 & 6.58 & 0.78 & 5.0 & 1.73 \\
\hline
\end{tabular}

DC: Dry Conditions; IC: Irrigation Conditions; B=Before SAR treatments (at the beginning of the experiment), $\mathrm{A}=\mathrm{After} \mathrm{SAR}$ treatments (at the end of the experiment).

Table 5: $\quad$ Magnesium levels (\%) in plant tissues before and after SAR.

\begin{tabular}{|c|c|c|c|c|c|c|c|c|c|c|c|c|}
\hline \multirow[t]{3}{*}{ Specie } & \multicolumn{12}{|c|}{ Treatment } \\
\hline & \multicolumn{2}{|c|}{$\begin{array}{c}\mathrm{pH} 2 \\
\mathrm{DC}\end{array}$} & \multicolumn{2}{|c|}{$\begin{array}{c}\mathrm{pH} 3 \\
\mathrm{DC}\end{array}$} & \multicolumn{2}{|c|}{$\begin{array}{c}\mathrm{pH} 2 \\
\mathrm{IC}\end{array}$} & \multicolumn{2}{|c|}{$\begin{array}{c}\mathrm{pH} 3 \\
\mathrm{IC}\end{array}$} & \multicolumn{2}{|c|}{$\begin{array}{c}\mathrm{pH} 4 \\
\mathrm{IC}\end{array}$} & \multicolumn{2}{|c|}{$\begin{array}{c}\mathrm{pH} 5.6 \\
\text { IC }\end{array}$} \\
\hline & $B$ & $A$ & B & $A$ & $B$ & $A$ & $B$ & A & $B$ & A & $B$ & A \\
\hline Red Mangrove & 2.65 & 3.83 & 2.8 & 3.47 & 1.72 & 2.89 & 2.48 & 4.09 & 2.36 & 3.18 & 2.19 & 2.86 \\
\hline White Mangrove & 3.07 & 5.06 & 3.45 & 4.44 & 3.74 & 3.71 & 3.97 & 3.49 & 3.79 & 2.37 & 3.09 & 3.44 \\
\hline Button Mangrove & 8.91 & 10.2 & 8.56 & 11.9 & 7.66 & 14.8 & 7.94 & 12.9 & 9.28 & 11.8 & 6.14 & 12.2 \\
\hline Mahogany & 2.73 & 1.7 & 2.29 & 1.22 & 2.07 & 1.5 & 1.81 & 1.42 & 2.72 & 1.66 & 1.69 & 1.79 \\
\hline Red Cedar & 3.84 & 5.99 & 3.48 & 5.17 & 2.88 & 4.8 & 4.09 & 3.24 & 3.18 & 3.31 & 2.86 & 3.6 \\
\hline Blood wood tree & 5.75 & 6.43 & 1.65 & 7.26 & 0.4 & 4.59 & 0.44 & 3.55 & 0.41 & 6.53 & 0.82 & 5.86 \\
\hline Pink flower tree & 5.92 & 2.68 & 4.66 & 2.89 & 2.41 & 1.57 & 2.61 & 2.22 & 2.92 & 4.2 & 2.88 & 2.78 \\
\hline
\end{tabular}

DC: Dry Conditions; IC: Irrigation Conditions; B=Before SAR treatments (at the beginning of the experiment), $\mathrm{A}=\mathrm{After} \mathrm{SAR}$ treatments (at the end of the experiment). 
Table 6: $\quad$ Manganese levels (\%) in plant tissues before and after SAR.

\begin{tabular}{|c|c|c|c|c|c|c|c|c|c|c|c|c|}
\hline \multirow[t]{3}{*}{ Specie } & \multicolumn{12}{|c|}{ Treatment } \\
\hline & \multicolumn{2}{|c|}{$\begin{array}{c}\mathrm{pH} 2 \\
\mathrm{DC}\end{array}$} & \multicolumn{2}{|c|}{$\begin{array}{c}\mathrm{pH} 3 \\
\mathrm{DC}\end{array}$} & \multicolumn{2}{|c|}{$\begin{array}{c}\mathrm{pH} 2 \\
\mathrm{IC}\end{array}$} & \multicolumn{2}{|c|}{$\begin{array}{l}\mathrm{pH} 3 \\
\mathrm{IC}\end{array}$} & \multicolumn{2}{|c|}{$\begin{array}{c}\mathrm{pH} 4 \\
\mathrm{IC}\end{array}$} & \multicolumn{2}{|c|}{$\begin{array}{c}\mathrm{pH} 5.6 \\
\mathrm{IC}\end{array}$} \\
\hline & $B$ & A & $B$ & $A$ & $B$ & $A$ & $B$ & $A$ & $B$ & $A$ & $B$ & $A$ \\
\hline Red Mangrove & 0.03 & 0.03 & 0.01 & 0.01 & 0.006 & 0.007 & 0.009 & 0.02 & 0.01 & 0.02 & 0.009 & 0.02 \\
\hline White Mangrove & 0.03 & 0.02 & 0.02 & 0.03 & 0.02 & 0.02 & 0.02 & 0.04 & 0.03 & 0.03 & 0.03 & 0.02 \\
\hline Button Mangrove & 0.03 & 0.05 & 0.03 & 0.06 & 0.02 & 0.05 & 0.02 & 0.04 & 0.033 & 0.05 & 0.04 & 0.06 \\
\hline Mahogany & 0.05 & 0.16 & 0.03 & 0.02 & 0.06 & 0.03 & 0.02 & 0.03 & 0.033 & 0.02 & 0.02 & 0.03 \\
\hline Red Cedar & 0.14 & 0.16 & 0.09 & 0.12 & 0.13 & 0.4 & 0.11 & 0.08 & 0.17 & 0.11 & 0.13 & 0.09 \\
\hline Blood wood tree & 0.56 & 0.38 & 0.24 & 0.37 & 0.19 & 0.22 & 0.19 & 0.77 & 0.18 & 0.21 & 0.14 & 0.32 \\
\hline Pink flower tree & 0.1 & 0.04 & 0.06 & 0.04 & 0.05 & 0.02 & 0.03 & 0.03 & 0.024 & 0.1 & 0.03 & 0.05 \\
\hline
\end{tabular}

DC: Dry Conditions; IC: Irrigation Conditions; $\mathrm{B}=\mathrm{Before}$ SAR treatments (at the beginning of the experiment), $\mathrm{A}=\mathrm{After} \mathrm{SAR}$ treatments (at the end of the experiment).

Table 7: $\quad$ Calcium levels (\%) in plant tissues before and after SAR.

\begin{tabular}{|c|c|c|c|c|c|c|c|c|c|c|c|c|}
\hline \multirow[t]{3}{*}{ Specie } & \multicolumn{12}{|c|}{ Treatment } \\
\hline & \multicolumn{2}{|c|}{$\begin{array}{c}\mathrm{pH} 2 \\
\mathrm{DC}\end{array}$} & \multicolumn{2}{|c|}{$\begin{array}{c}\mathrm{pH} 3 \\
\mathrm{DC}\end{array}$} & \multicolumn{2}{|c|}{$\begin{array}{c}\mathrm{pH} 2 \\
\mathrm{IC}\end{array}$} & \multicolumn{2}{|c|}{$\begin{array}{c}\mathrm{pH} 3 \\
\mathrm{IC}\end{array}$} & \multicolumn{2}{|c|}{$\begin{array}{c}\mathrm{pH} 4 \\
\mathrm{IC}\end{array}$} & \multicolumn{2}{|c|}{$\begin{array}{c}\mathrm{pH} 5.6 \\
\mathrm{IC}\end{array}$} \\
\hline & $B$ & A & B & A & B & A & $B$ & A & B & A & B & A \\
\hline Red Mangrove & 3.14 & 4.73 & 2.91 & 4.02 & 2.75 & 4.85 & \begin{tabular}{|l|l}
4.28 \\
\end{tabular} & \begin{tabular}{|l|}
11.1 \\
\end{tabular} & 3.2 & 4.5 & 2.93 & 4.57 \\
\hline White Mangrove & 4.81 & 5.3 & 4.99 & 6.4 & 7.05 & 11.4 & 5.0 & 7.77 & 5.17 & 14.6 & 4.66 & 5.64 \\
\hline Button Mangrove & 1.73 & 4.87 & 1.59 & 8.41 & 0.98 & 5.22 & 1.26 & 4.88 & 3.53 & 9.17 & 1.8 & 8.5 \\
\hline Mahogany & 2.7 & 1.31 & 1.6 & 1.3 & 3.09 & 1.52 & 2.89 & 1.08 & 2.19 & 1.36 & 1.57 & 1.61 \\
\hline Red Cedar & 3.24 & 6.76 & 2.42 & 3.5 & 5.13 & 5.73 & 2.89 & 2.66 & 5.33 & 3.19 & 3.55 & 2.87 \\
\hline Blood wood tree & 14.4 & 8.76 & 6.74 & 7.16 & 2.99 & 4.92 & 3.23 & 18.3 & 4.7 & 5.07 & 4.03 & 6.0 \\
\hline Pink flower tree & 3.12 & 1.73 & 2.72 & 1.59 & 1.79 & 0.98 & 1.69 & 1.26 & 1.63 & 3.53 & 1.42 & 1.8 \\
\hline
\end{tabular}

DC: Dry Conditions; IC: Irrigation Conditions; B=Before SAR treatments (at the beginning of the experiment), $\mathrm{A}=\mathrm{After} \mathrm{SAR}$ treatments (at the end of the experiment).

concentrations decreased after SAR treatments were applied. In this study, nutrients levels were quantified before and after the controlled exposure to SAR. From the results of Table 4 , it can be observed that potassium levels in vegetal tissue decreased in all cases, being this decrease greater in button mangle, mahogany, and red mangrove at $\mathrm{pH} 2$ and 3 under irrigation and drought conditions. On the other hand, it was not observed a clear tendency in magnesium data (Table 5).

From Table 6, it can be observed that Mn levels in vegetal tissue increased in blood wood tree, red cedar, button mangrove, and red mangrove, possibly due to acid-induced increased solubility of the cations in the soil. In addition, it can be observed (From Table 7) that calcium levels in leaves of red cedar, button mangrove, blood wood tree, red mangrove and white mangrove increased as a result of SAR treatments, especially at $\mathrm{pH} 2$ and 3 under dry and irrigation conditions. 


\subsection{SAR effects on the water stress condition}

Our results suggest that water stress condition of studied individuals predispose them to suffer damage more severe. In all cases, individuals exposed to acid rain under dry conditions were more susceptible to visible injuries, showing a decreasing in photosynthetic pigments, increasing in sulphur levels and nutrients imbalance. From these results it can be inferred that the occurrence of acid rain events among dry periods can have severe consequences on sensitive vegetation species. In places with a monsoon climate like Southeast of Mexico, midsummer drought is a common meteorological phenomenon (Mid-summer drought constitutes a relative minimum between two peaks of maximal precipitation during rainy season, and usually it takes place in August). On the other hand, at the beginning of the rainy season, acid rain episodes after long dry periods can take place in May. Therefore, we could identify two critical periods along year in the region of Campeche, in which plants can be more sensitive to acid rain episodes.

\subsection{Identification of sensitive species with potential to be used as bioindicators}

In general, all studied species showed sensitivity to SAR, but, considering the observed effects on photosynthetic pigments, sulphur and nutrient levels, we can propose the three mangrove species, red cedar and blood wood tree as sensitive species with potential to be used as bioindicators in the region of Campeche.

\section{Conclusions}

Severe visible damage observed was similar to symptoms reported for chlorosis and necrosis induced by acid rain. Nutrient levels were sensitive to lowest $\mathrm{pH}$ values. After SAR treatments, potassium levels decreased and calcium and manganese levels increased. According to the results, it could be observed that Red mangrove, Button mangrove, White mangrove, Red cedar and Blood wood tree were more sensitive to acid rain, and they can be suggested as regional bioindicators of atmospheric pollution. The Horsfall-Barratt method was applied to develop a severity scale; however, it is necessary to conduct field survey for long-term exposures in parcels focused on sensible species to obtain a more accurate scale.

\section{References}

[1] McLaughlin, S.B; and Shriner, D.S. (1980). Allocation of resources to defence and repair. In Plant diseases, ed. J.B. Horsfall and E.B. Cowling. Vol. 5. Academic Press. New York. 407-431.

[2] Troiano, J; Colavito, L; Heller, L; McCune, D.C; and Jacobson, J.S. (1983). Effects of acidity of simulated rain and its joint action with ambient ozone 
on measures of biomass and yield in soybean. Environ. Exp. Bot. 23: 113119.

[3] Percy, K. (1986). The effects of simulated acid rain on germinative capacity, growth and morphology of forest tree seedlings. New. Phytol. 104: 473-484.

[4] Jacobson, J.S; Heller, L.I; Yamada, K.E; Osmeloski, J.F; Bethard, T; and Lassoie, J.P. (1990). Foliar injury and growth response of red spruce to sulfate and nitrate acidic mist. Can. J. For. Res. 20: 58-65.

[5] Shepard, L.J; Cape, J.N; and Leith, I.D. (1993). Influence of acidic mist on frost hardiness and nutrient concentrations in red spruce seedlings. 1. Exposure of the foliage and the rooting environment. New Phytol. 124: 595-605.

[6] Abouguendia, Z.M; and Baschak, L.A. (1987). Responses of two western Canadian conifers to simulated acid precipitation. Water, Air \& Soil Pollution. 33: 15-22.

[7] Billen, N; Schätzle, H; Seufert, G; and Arndt, U. (1990). Performance of some growth variables. Environ. Pollut. 68: 419-434.

[8] Bäck, J; Huttunen, S; Turunen, M; and Lamppu, J. (1995). Effects of acid rain on growth and nutrient concentrations in Scots pine and Norway spruce seedlings grown in a nutrient-rich soil. Environ. Pollut. 89. 2: 177187.

[9] Houbao, F; and Chuanrong, L. (1999). Effects of simulated acid rain on seedling emergence and growth of five broad-leaved species. J. For. Res. 10. 2: 83-86. Evans, L.S; Gmur, N.F; and Da Costa, F. (1977). Leaf surface and historical perturbations of leaves of Phaseolus vulgaris and Helianthus annuus after exposure to simulated acid rain. Am. J. Bot. 64: 903.

[10] Evans, L.S; Gmur, N.F; and Da Costa, F. (1977). Leaf surface and historical perturbations of leaves of Phaseolus vulgaris and Helianthus annuus after exposure to simulated acid rain. Am. J. Bot. 64: 903.

[11] Ferenbaugh, R.W. (1976). Effects of simulated acid rain on Phaseolus vulgaris L. (Fabaceae). Am. J. Bot. 63: 283-288.

[12] Jacobson, J.S. and Van Leuken, P. (1977). Effects of acidic precipitation on vegetation. In: Proc. Of the fourth International Clean Air Congress, Tokyo. May 16-20. 124-127.

[13] Shriner, D.S. (1976). Effects of simulated rain acidified with sulfuric acid on host-parasite interactions. In: Proc. First Intern. Symp. On Acid Precip. And the Forest Ecosystem, (L.S. Dochinger and T.A. Seliga eds.). U.S. For. Serv., Gen. Tech. Rep. NE-23. 919-925.

[14] Wood, T. and Bormann, F.H. (1974). The effects of an artificial acid mist upon the growth of Betula alleghaniensis Britt. Environ. Pollut. 7: 259-268.

[15] Haines, B.L; and Carlson, C.L. (1989). Effects of acidic precipitation on trees. In: Acidic precipitation 2. Springer-Verlag.

[16] Shriner, D.S; Heck, W.W; and McLaughlin, S.B. (1990). Response of vegetation to atmospheric deposition and air pollution. NAPAP SOS/T Report 18. 
[17] Kohno, Y; Matsumura, H; and Kobayashi, T. (1994). Effect of simulated acid rain on the development of visible injuries in tree seedlings. J. Japan Soc. Air. Poll. 29: 206-219.

[18] Tamm, C.O. and Popovic, B. (1989). Acidification experiments in pine forests. National Swedish Environmental Protection Board. Report 3589.

[19] Tveite, B; Abrahamsen, G; and Stuanes, A.O. (1990/1991). Liming and wet acid deposition effects on tree growth and nutrition: Experimental results. Water, Air and Soil Pollution. 54: 409-422.

[20] Izuta, T. and Miwa, M. (1990). Growth response of Cryptomeria seedlings to simulated acid rain. Man \& Environ. 16: 44-53.

[21] Miwa, M; Izuta, T; and Totsuka, T. (1993). Effects of simulated acid rain and/or ozone on the growth of Japanese cedar seedlings. J. Japan. Soc. Air. Pollut. 28: 279-287.

[22] Matsumoto, Y. and Maruyama, Y. (1992). Some negative results of simulative acid mist and ozone treatments to Cryptomeria japonica seedlings in explanation of mature $C$. japonica decline in the Kanto plains in Japan. Jpn. J. For. Environ. 34: 85-97.

[23] NOM-059-SEMARNAT-2001. Protección Ambiente. Especies Nativas de México de Flora y Fauna Silvestres-categorías de riesgo y especificaciones para su inclusión, exclusión o cambio-Lista de especies en Riesgo.

[24] SAS Institute Inc. SAS/STAT Guide for personal computers. The SAS System for Windows V. 8. United States of America.

[25] Osada, V.H. and Mora, G. (1997). DosLog V.1. Colegio de Postgraduados, Montecillo. Texcoco, Estado de México. Free Software.

[26] Izuta, T; Yamaoka, T; Nakaji, T; Yonekura, T; Yokoyama, M; Funada, R; Koike, T; and Totsuka, T. (2004). Growth, net photosynthesis and leaf nutrient status of Fagus crenata seedlings grown in brown forest soil acidified with $\mathrm{H}_{2} \mathrm{SO}_{4}$ or $\mathrm{HNO}_{3}$ solution. Trees. 18: 677-685.

[27] Hogan, G.D. (1998). Effect of simulated acid rain on physiology, growth and foliar nutrient concentrations of sugar maple. Chemosphere. 36. 4: 633638.

[28] Izuta, T; Yamaoka, T; Nakaji, T; Yonekura, T; Yokoyama, M; Matsumura, H; Ishida, S; Yakazi, K; Funada, R; and Koike, T. (2001). Growth, net photosynthetic rate, nutrient status and secondary xylem anatomical characteristics of Fagus crenata seedlings grown in brown forest soil acidified with H2SO4 solution. Water, Air \& Soil Pollution. 130: 10071012.

[29] Shan, Y; Izuta, T; Aoki, M; and Totsuka, T. (1997). Effects of $\mathrm{O}_{3}$ and soil acidification, alone and in combination, on growth, gas exchange rate and chlorophyll content of red pine seedlings. Water, Air and Soil Pollution. 97: 355-366. 